\title{
Metastatic cutaneous melanoma in equine: anatomopathological aspects
}

\section{Melanoma cutâneo metastático em equino: aspectos anatomopatológicos}

\section{Ismael Lira Borges ${ }^{1}$, Telma de Sousa Lima ${ }^{1}$, Rodolfo Gurgel Vale ${ }^{2}$, Pedro Augusto Cordeiro Borges ${ }^{2}$, Jael Soares Batista ${ }^{3}$, Kilder Dantas Filgueira ${ }^{4 *}$}

\begin{abstract}
Cutaneous melanoma is a neoplasm originating from melanocytes. In equines, a variable incidence of 6 to $14 \%$ of the total tegumentary neoplasms. The occurrence of metastasis is uncommon. In this sense, the objective was to describe a case of metastatic cutaneous melanoma in the equine species. A 15-year-old mixed-breed mare, died and was sent to perform necroscopic examination. During the processing of samples of various tissues and organs submitted to histopathological analysis. The main macroscopic alterations observed corresponded to proliferations in cutaneous glandular tissue of the udder, mammary lymph nodes, heart, lung, parietal pleura, liver and spleen, with sometimes blackened cutting surface. The morphological pattern, throughout the udder tissue extension, was compatible with melanoma. Histopathological evaluation of the two affected organs revealed a similar microscopic appearance. When associating the anatomopathological findings, a picture of metastatic cutaneous melanoma was defined. Melanoma should be considered as one of the possible diseases that affect the integument wrapping of the udder of mares of advanced age. A thorough evaluation of the animal is useful, since the metastatic potential is a real possibility.
\end{abstract}

Keywords: neoplastic melanocytes, systemic dissemination, Equus caballus

Resumo: O melanoma cutâneo é uma neoplasia oriunda dos melanócitos. Em equinos, a incidência varia de 6 a $14 \%$ do total das neoplasias tegumentares. A ocorrência de metástase é incomum. Nesse sentido, objetivou-se descrever um caso de melanoma cutâneo de padrão metastático na espécie equina. Uma égua, 15 anos, mestiça, veio a óbito e foi encaminhada para execução de exame necroscópico. Durante o procedimento foram coletadas amostras de vários tecidos e órgãos, sendo submetidas à análise histopatológica. As principais alterações macroscópicas observadas corresponderam a proliferações em tecido cutâneo/glandular do úbere, linfonodos mamários, coração, pulmão, pleura parietal, fígado e baço, com superfície de corte por vezes enegrecida. O padrão morfológico, em toda a extensão do tecido do úbere, foi compatível com melanoma. A avaliação histopatológica dos demais órgãos acometidos revelou aspecto microscópico similar. Ao associar os achados anatomopatológicos, definiu-se um quadro de melanoma cutâneo metastático. Deve-se considerar o melanoma como uma das possíveis enfermidades que acometem o tegumento envoltório do úbere de éguas de idade avançada. Torna-se necessária uma avaliação minuciosa do animal, uma vez que o potencial metastático é uma real possibilidade.

Palavras chave: melanócitos neoplásicos, disseminação sistêmica, Equus caballus

\footnotetext{
*Author for correspondence: E-mail: kilder@ufersa.edu.br

Recebido em 10.11.2016. Aceito em 28.03.2017

${ }^{1}$ Veterinarian, Resident in Animal Pathology, Veterinary Hospital, Universidade Federal de Campina Grande (UFCG). E-mail: ismael.borges@aluno.uece.br

${ }^{2}$ Veterinarian, Resident in Clinical and Surgery of Large Animals, Veterinary Hospital, Universidade Federal Rural do Semi-Árido (UFERSA). E-mail: pedroavet@ yahoo.com.br

${ }^{3}$ Professor, Doctor, Department of Animal Science, Universidade Federal Rural do Semi-Árido (UFERSA). E-mail: jael.batista@ufersa.edu.br

${ }^{4}$ Veterinarian, Master, Veterinary Hospital, Universidade Federal Rural do Semi-Árido (UFERSA). Email: kilder@ufersa.edu.br
}

http://dx.doi.org/10.5935/1981-2965.20170004 


\section{Introduction}

Oncology is a specialty of veterinary medicine that has been growing in recent years, mainly involving dogs and cats, since the close relationship between humans and pets results in an increase in their life expectancy. Regarding the species of production, the occurrence of tumors is relatively minor, either because of the scarcity of reports or even by the destiny conceived for the individuals, which in most cases is the discard or the slaughter, reflecting in an underdiagnosis of the oncopatias (RAMOS et al., 2008). In Brazil, among equine and bovine animals, cattle are the most affected by neoplasias (RAMOS et al., 2008; CARVALHO et al., 2014). In the equine species, cutaneous neoplastic proliferations are the most frequent, accounting for about $50 \%$ of all tumors of the species, especially sarcoids, squamous cell carcinomas, papillomas and melanomas (VALENTINE, 2006; RAMOS et al., 2008; CARVALHO et al., 2014).

In relation to melanoma, it originates from epidermal melanocytes (or melanoblasts) and the incidence in horses ranges from 6 to $14 \%$ of all cutaneous neoplasms. Longevity contributes to the occurrence, since the involvement is verified mainly in adult animals to the elderly (VALENTINE, 2006).

Melanocytic proliferations may be single or multiple and usually localized in the cervical, ocular, perineal and coccygeal regions (PEREIRA, 2011).
The diagnosis of melanoma is based on epidemiological and clinical data, but the histopathological analysis is confirmatory, allowing the establishment of prognosis and the possibility of establishing therapeutic management, such as surgical excision (PEREIRA, 2011). The detection of metastases is uncommon and with unknown incidence, but when present reflects on an unfavorable prognosis (MACGILLIVRAY et al., 2002).

Equines represent an important source of income in relation to international trade, such as the use of animals, for example, for sports, and therefore studies that address the health of the species are relevant. Therefore, the interest in diagnosing (and if possible) solving dermatological neoformations in horses is growing every year due to the fact that thes lesions lead to economic losses, as well as being an aesthetic problem (SPRENGER et al., 2014).

In the case of cutaneous melanomas, a detailed clinical-pathological evaluation is essential, as well as the establishment of possible differential diagnoses. Thus, the present study aimed at describing a case of metastatic tegumentary melanoma in equine, emphasizing the main anatomopathological changes observed and the distinction with other diseases that mimic such neoplastic proliferation.

\section{Material and Methods}

An entire mare, 15-year-old, mixed-breed and gray-haired, had a history of apathy, anorexia, and weight loss. The animal was 
submitted to physical evaluation. Due to the state of the animal, it passed to death after the care.

The equine was referred for necroscopic examination. During the procedure, samples of various tissues and organs were collected and fixed in $10 \%$ formalin solution. Subsequently the material was submitted to classical histopathological analysis.

\section{Results and Discussion}

The clinical examination showed that the animal remained in lateral decubitus (with a time of evolution of three days), nutritional state cachexia, hypocoratous mucosa, dyspnea and dehydration. The udder was also found to be enlarged, with firm consistency on palpation and local hyperthermia, suggesting at first a mastitis pattern. There was no report of the time of evolution of the alteration in the mammary region and the institution of previous therapies was absent. The main macroscopic changes observed during necropsy are shown in Table 1 and Figure 1.

Table 1. Demonstration of affected regions, number of nodules/tumors and description of macroscopic aspects of the same.

\begin{tabular}{ccc}
\hline Location & $\begin{array}{c}\text { Number of } \\
\text { nodules/tumors }\end{array}$ & Description \\
\hline $\begin{array}{c}\text { Cutaneous and } \\
\text { glandular tissue of } \\
\text { udder }\end{array}$ & Only one & $\begin{array}{c}\text { Firm, irregular, compact, non-ulcerated tumor. Sagittal section: } \\
\text { surface blackened and interspersed with areas sometimes grayish or } \\
\text { yellowish. }\end{array}$ \\
\hline $\begin{array}{c}\text { Lymph nodes of } \\
\text { the mammary } \\
\text { gland }\end{array}$ & Only one & $\begin{array}{c}\text { Firm and compact nodule. When cutting: surfasse firm, blackened } \\
\text { interspersed with areas sometimes grayish or yellowish. }\end{array}$ \\
\hline $\begin{array}{c}\text { Heart* } \\
\text { pleura }\end{array}$ & Four & $\begin{array}{c}\text { Nodules firm, of varied sizes. Sagittal section: greyish to blackish } \\
\text { and compact. }\end{array}$ \\
& Multiples & $\begin{array}{c}\text { Lung: nodules, firm, whitish to blackened and diffuse throughout the } \\
\text { parenchyma. Sagittal section: multissept, compact, whiteish surface } \\
\text { with blackened streaks. Pleura: irregular nodules, blackish, soft and } \\
\text { lumpy. }\end{array}$ \\
& & $\begin{array}{c}\text { Nodules and tumors, firm, of varied sizes, whitish to grayish, } \\
\text { parietal }\end{array}$ \\
& Multiples & $\begin{array}{c}\text { Firm nodules and tumors. Sagittal section: irregular surface, } \\
\text { grayish to whitish with central area of necrosis. }\end{array}$ \\
\hline Liver & Multiples &
\end{tabular}

*Left ventricular myocardium (two nodules); myocardium of the left atrium (a nodule); epicardium of the interventricular septum region (a nodule). 

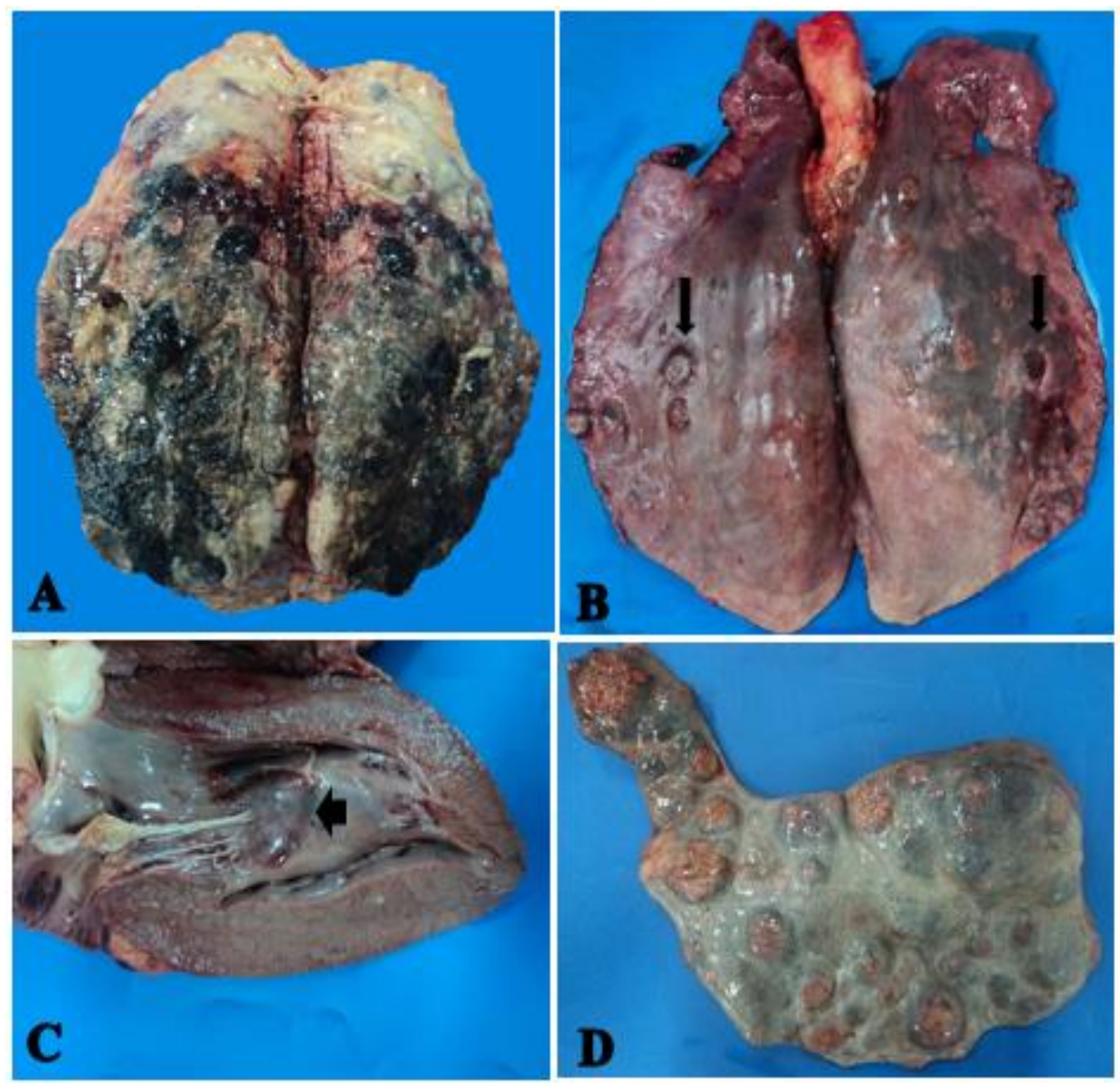

Figure 1. Macroscopic appearance of melanocytic proliferations at primary site and respective metastases. Udder (A), corresponding to the probable place of origin of the neoplasia. Secondary lesions: lung (B), heart (C) and spleen (D). The cutting surface of the udder appears irregular and blackish; aspect of the pulmonary nodules (fine arrows); left ventricular myocardium nodule (broad arrow); multiple nodules and tumors in the spleen.

irregular, pleomorphic, with accentuated

Microscopically, the udder tissue exhibited, in all its extension, a proliferation consisting of little differentiated neoplastic cells that grew on dense connective, sometimes cirrhotic stroma, forming cords or of compact form. The cytoplasm was eosinophilic and with indistinct borders. The nucleus presented anisocariasis and one or more atypical nucleoli. In some areas we observed neoplastic cells containing melanocyte-compatible intracytoplasmic pigment.

Mitosis figures were frequent, aberrant and multipolar. The morphological pattern was compatible with melanoma. 
The histopathological evaluation of the other affected organs (according to Table 1) revealed a similar microscopic appearance (Figure 2). Bone fragments were also analyzed, and malignant neoplastic melanocytic cells from precursor and mature cells were found in the medullary canal, with partial replacement of hematopoietic tissue (Figure 2).

When the clinical, necroscopic (macroscopic) and histopathological findings were associated, a metastatic cutaneous melanoma was defined.
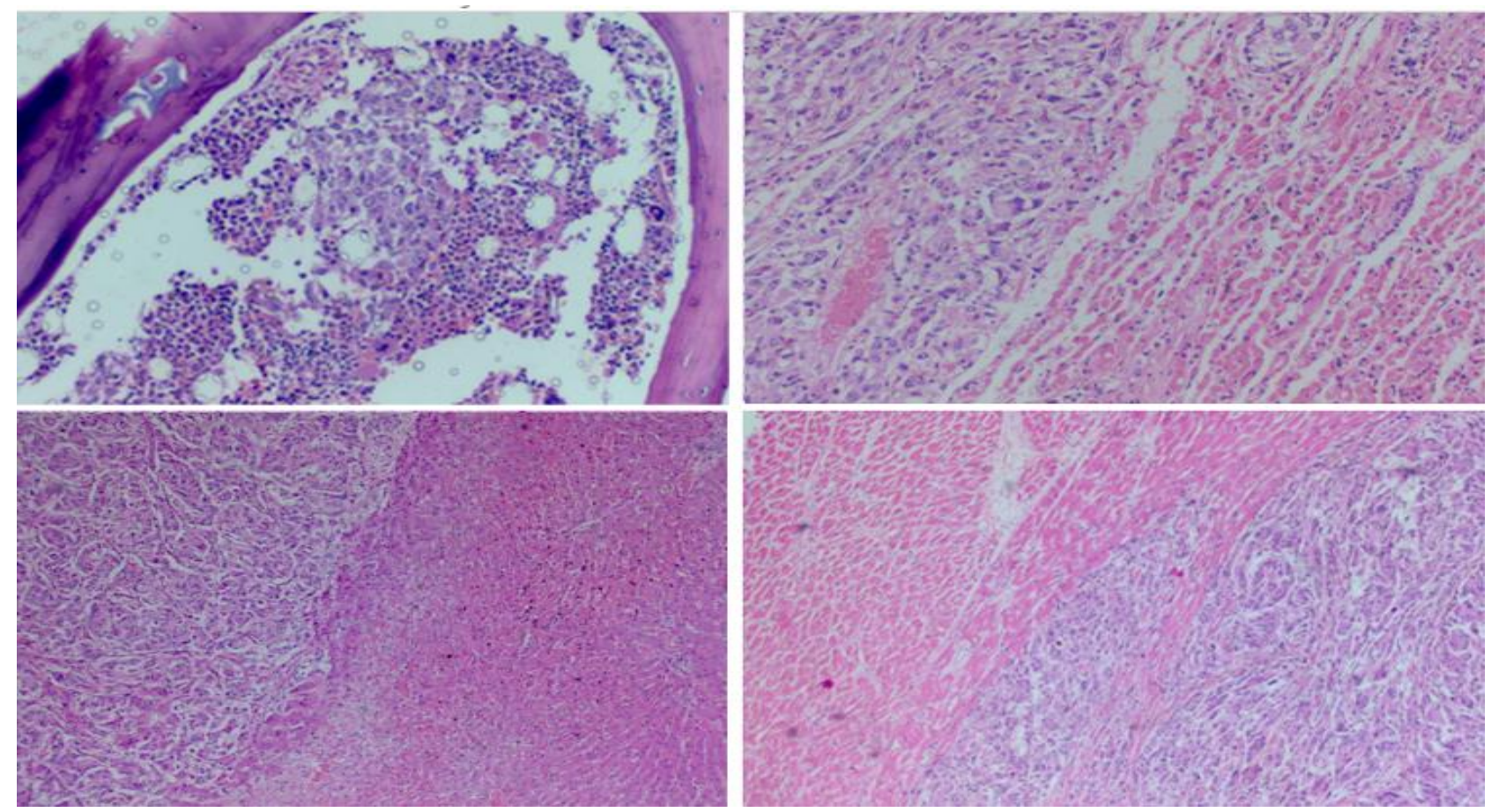

Figure 2. Histopathological appearance of cutaneous melanoma metastases in horse. A: bone marrow exhibiting neoplastic infiltration (at the center) of permeation with the hematopoietic cells (staining: hematoxylin-eosin; objective: 20x). B: pulmonary tissue revealing the focus of pleomorphic neoplastic cells (on the left) surrounding atelectatic alveoli (staining: hematoxylin-eosin; objective: 20x). C: liver evidencing area of neoplastic implantation (on the left), adjacent to the hepatocyte cords (staining: hematoxylin-eosin; objective: 10x). D: cardiac tissue elucidating invasion of neoplastic cells (on the right) through the muscle fibers (staining: hematoxylin-eosin; objective: 10x).

The horses of advanced age and of graying color are apparently predisposed to the occurrence of cutaneous melanoma (PATTERSON-KANE et al., 2001; MACGILLIVRAY et al., 2002; PEREIRA, 2011). Such epidemiological data were compatible with the case described. Cutaneous melanoma represents one of the most serious neoplasms of higher frequency in horses (CAMPOS et al., 2008). The clinical signs exhibited by the affected animals are generally non-specific and associated with the primary neoplastic location and possible metastases (MACGILLIVRAY et al., 2002; SMITH et al., 
2002; RISSI et al., 2008). In this sense, for the animal in question, the symptomatology presented was justified by the local tumor action and distance.

According to Pereira (2011) and Scott \& Miller (2011), cutaneous melanomas in the equine species have greater occurrence on the ventral surface of the tail, perineal region, labial commissures and periorbital area. For the present report, divergence occurred in relation to areas commonly affected by neoplasia. It is noteworthy that melanomas in the tegumentary region associated with the udder are rare in mares (MENDES, 2015), which reinforces the unusual character of the record in evidence.

The metastatic sites usually detected from cutaneous melanomas of the equine include liver, spleen, kidney, diaphragm, aorta and guttural sac (MACGILLIVRAY et al., 2002). In the animal under

discussion, there was only partial agreement regarding the presentation of the visceral (metastatic or secondary) sites of the original melanocytic tegumentary neoplasia. In horses, dogs and humans, cutaneous melanomas rarely result in infiltration of neoplastic melanocytes into the bone marrow (PATTERSON-KANE et al., 2001; JAIN et al., 2007; KYM et al., 2009). Therefore, the neoplastic dissemination to the medullary canal of the described animal was considered as a peculiar circumstance and gave an aspect of greater severity to the prognosis. In some human cases, the neoplasia is detected in the bone marrow even without identifying the primary proliferation in other organs, suggesting that the original tumor has regressed (JAIN et al., 2007). However, no such involution was observed in this case, but the distribution of the metastatic neoplastic cells in the patient's bone marrow highlighted the importance of performing cytological analyzes of the bone marrow during the approach (still in vivo) of equines affected by tegumentary melanomas.

Equine cutaneous melanoma does not present great morphological variations, by means of the verification of previous studies, however, solitary or multiple primary nodules with a diffuse multifocal dissemination pattern varying from whitish to blackened can be found in the parenchyma of the affected organs (SMITH et al., 2002; RISSI et al., 2008; SCOTT \& MILLER, 2011). This macroscopic characterization was shown to be compatible with the findings of the reported specimen.

Differential diagnoses for cutaneous melanoma in the mammary area of mares should include all processes involving increased udder volume, such as mastitis, primary neoplasms of the breast tissue (adenoma, carcinoma, lymphoma, sarcoma, malignant fibrohistiocytoma), galactorrhea, traumas, aberrant larvae migrations, botryomycosis and cutaneous histoplasmosis, periparturient edema, avocado intoxication, among others (REESINK et al., 2009; MENDES et al., 2011; SMIET et al., 2012; MENDES, 2015). Therefore, this wide variety of conditions mimicking cutaneous melanoma associated with the equine udder 
Borges et al., Revista Brasileira de Higiene e Sanidade Animal, v.11, n.1, p. 32-38, jan-mar, 2017

could have been included in the clinical differentiation of the neoplastic disease if it had been detected early or had more consistent data in the anamnesis.

\section{Conclusion}

Melanoma should be considered as a differential diagnosis for diseases that affect the womb integument of the udder of mares of advanced age. A thorough evaluation of the animal is necessary to verify whether the process remains restricted or disseminated, since the metastatic potential is a real possibility and with a negative prognostic reflex.

\section{References}

1.CAMPOS, A. G. S. S.; SANTOS, R.A.; MOTA, A. E. R.; MAIA, F. C. L.; SOUZA, J.C.A.; AFONSO, J. A. B.; MENDONÇA, C.L. Melanoma equino. Ciência Veterinária nos Trópicos, v.11, n.2/3, p.7680, 2008.

2. CARVALHO, F. K. L.; DANTAS, A. F. M.; RIET-CORREA, F.; ANDRADE, R. L. F. S; NOBREGA-NETO, P. I.; MIRANDA-NETO, E. G.; SIMÕES, S.V.D.; AZEVEDO, S.S. Estudo retrospectivo das neoplasias em ruminantes e equídeos no semiárido do Nordeste Brasileiro. Pesquisa Veterinária Brasileira, v.34, n.3, p.211216, 2014.

3. JAIN, D.; SING, T.; KUMAR, N.; DAGA, M.R. Metastatic malignant melanoma in bone marrow with occult primary site - a case report with review of literature. Diagnostic Pathology, v.2, n.38, p.1-4, 2007.

4. KYM, D.Y.; ROYAL, A.B.; VILLAMIL, J.A. Disseminated melanoma in a dog with involvement of leptomeninges and bone marrow. Veterinary Pathology, v.46, n.1, p.80-83, 2009.

5. MACGILLIVRAY, K.C.; SWEENEY, R.W.; PIERO, F.D. Metastatic melanoma in horses. Journal of Veterinary Internal Medicine, v.16, n.4, p.452- 456, 2002.
6. MENDES, L.C.N. Mammary tumors. In: SPRAYBERRY, K.A.; ROBINSON, N.E. (Ed). Robinson's - Current therapy in equine medicine. 7.ed. St. Louis: Elsevier, 2015. cap.101, p.432-434.

7. MENDES, L.C.N.; ARAÚJO, M.A.; BOVINO, F.; ROZZA, D.B.; MACHADO, G.F.; CADIOLI, F.A.; FEITOSA, F.F.L.; PEIRÓ, J. R. Clinical, histological and immunophenotypic findings in a mare with a mammary lymphoma associated with anaemia and pruritus. Equine Veterinary Education, v.23, n.4, p.177-183, 2011.

8. PATTERSON-KANE, J.C.; SANCHEZ, L.C.; UHL, E.W.; EDENS, L.M. Disseminated metastatic intramedullary melanoma in an aged grey horse. Journal of Comparative Pathology, v.125, n. 2-3, p.204-207, 2001.

9. PEREIRA, A.M.S.M. Tumores melanocíticos em equinos-estudo clínico, histopatológico e imunohistoquímico. Vila Real, 2011. 61p. Dissertação (Mestrado Integrado em Medicina Veterinária) - Universidade de Trás-os-Montes e Alto Douro, 2011.

10. RAMOS, A.T.; SOUZA, A.B.; NORTE, D.M.; FERREIRA, J.L.M.; FERNANDES, C.G. Tumores em animais de produção: aspectos comparativos. Ciência Rural, v.38, n.1, p.148-154, 2008.

11. REESINK, H.L.; PARENTE, E.J.; SERTICH, P.L.; ENGILES, J.B. Malignant fibrous histiocytoma of the mammary gland in a mare. Equine Veterinary Education, v.21, n.9, p.467-472, 2009.

12. RISSI, D.R.; FIGHERA, R.A.; IRIGOYEN, L.F.; LACORTE, F.D.; BARROS, C.S.L. Melanoma maligno anaplásico em um equino. Ciência Rural, v.38, n.7, p.2072- 2075, 2008.

13. SCOTT, D.; MILLER, W. Equine Dermatology. 2.ed. Maryland Heights: Elsevier, 2011. 536p.

14. SMIET, E.; GRINWIS, G.C.M.; VAN DEN TOP, J.G.B.; SLOET VAN OLDRUITENBORGH OOSTERBAAN, M. M. Equine mammary gland disease with a focus on botryomycosis: A review and case study. Equine Veterinary Education, v.24, n.7, p.357-366, 2012. 